\title{
Regulations Pertaining to Non-native Fish in Florida Aquaculture ${ }^{1}$
}

Jeffrey E. Hill ${ }^{2}$

\section{Introduction}

Florida aquaculture is extremely diverse, with commercial production of a wide variety of warm water and tropical species of ornamental, food, bait, and sport fish. In 2003, the farm-gate value of Florida aquaculture was US\$95.5 million, with over $49 \%$ of that value in ornamental fish (FASS 2004). The ornamental segment of Florida aquaculture is dominated by the production of non-native species. Other non-native species such as tilapia and sturgeon are produced for food, and grass carp is produced for control of aquatic weeds.

Although non-native aquatic organisms are important to Florida aquaculture and the economy of the state, the culture of non-native fish presents challenges to the industry and to natural resource authorities in Florida. In particular the aquaculture industry should be aware of the considerable local, state, and national concern over the potential ecological, economic, or human health problems arising from non-native fish in natural environments (e.g., competition with native species). Florida's large human population, numerous aquaculture production facilities, abundant water, and warm climate can allow non-native species to be introduced, become established, and thrive. Currently, there are over 30 species of non-native freshwater fish reproducing in Florida (Hill 2002; FWC 2005; USGS 2005). Although Florida producers culture or have cultured nearly all of these species, introductions also occur by a variety of other means such as legal intentional releases for sport fishing and aquatic weed control, and illegal releases of pet fish by aquarium hobbyists. Regardless of the actual source of the introduction (e.g., aquaculture escape or aquarium release), unplanned introductions are illegal and undesirable.

In Florida, there are two agencies primarily responsible for regulating the use of non-native species in aquaculture - the Florida Fish and Wildlife Conservation Commission (FWC) and the Florida Department of Agriculture and Consumer Services (DACS), Division of Aquaculture. The Institute of Food and Agricultural Sciences (IFAS) of the University of Florida assists these agencies by conducting research related to non-native species and by providing extension services to the aquaculture industry. In addition to these state agencies, the United States Fish and Wildlife Service (USFWS)

1. This document is FA-121, one of a series of the Fisheries and Aquatic Sciences Department, Florida Cooperative Extension Service, Institute of Food and Agricultural Sciences, University of Florida. Original publication date August 2006. Visit the EDIS Web Site at http://edis.ifas.ufl.edu.

2. Jeffrey E. Hill, Assistant Professor, Tropical Aquaculture Laboratory, Department of Fisheries and Aquatic Sciences, Institute of Food and Agricultural Sciences, University of Florida, 1408 24th Street SE, Ruskin, FL 33570

The Institute of Food and Agricultural Sciences (IFAS) is an Equal Opportunity Institution authorized to provide research, educational information and other services only to individuals and institutions that function with non-discrimination with respect to race, creed, color, religion, age, disability, sex, sexual orientation, marital status, national origin, political opinions or affiliations. U.S. Department of Agriculture, Cooperative Extension Service, University of Florida, IFAS, Florida A. \& M. University Cooperative Extension Program, and Boards of County Commissioners Cooperating. Larry Arrington, Dean 
regulates the importation of wildlife species (including fish and other aquatic organisms) and their interstate trade. This publication provides a brief overview of the roles of each agency and the regulations pertaining to the use of non-native fish in Florida aquaculture.

As a word of caution, regulations change and this publication serves only as a guide to familiarize interested parties with the regulatory framework for Florida. In addition, this publication concentrates on regulations pertaining to non-native fish; regulations for other non-native aquatic organisms (e.g., snails and plants) may differ. For more information, contact FWC, DACS Division of Aquaculture, or other appropriate agency (see Appendix for contact information).

\section{Florida Fish and Wildlife Conservation Commission (FWC)}

The FWC is the agency with primary legal responsibility for regulating and managing Florida's fish and wildlife resources (Florida Constitution 2005). It prohibits the release of non-native fish and other aquatic organisms without a permit (FAC 2003; Florida Statutes 2004 a,b).

The FWC maintains lists of prohibited (Table 1) and restricted (Table 2) freshwater species and regulates their possession, sale, and use in Florida. Prohibited species (or their hybrids) may not be imported, sold, possessed, or transported in Florida; limited exceptions are made for public aquaria and scientific research (FAC 2003). Some saltwater species also are prohibited and may not be imported (Table 1; Florida Statutes 2004a). Permits for possession of prohibited freshwater species are issued by the Division of Law Enforcement following consultation with the divisions of Freshwater Fisheries and Habitat and Species Conservation. Restricted species may be possessed only under permit from FWC (FAC 2003), unless authorized under an aquaculture certificate from DACS. Permits may be granted to commercial aquaculture facilities (through DACS), public aquaria, or for scientific research. Any facility housing restricted species must have adequate safeguards to prevent escape or accidental release of adults, juveniles, or eggs.
Outdoor facilities must have pond banks at least a foot above the 100-year flood elevation, be secure from public intrusion, and have no discharge to waters of the state or have barriers to prevent escape in discharge (FAC 2003). Similarly, indoor facilities must be secure and have screened or no discharge.

Table 1. Fish and other aquatic organisms prohibited in Florida.

\begin{tabular}{|c|}
\hline a. Freshwater ${ }^{1}$ \\
\hline African electric catfishes (Malapteruridae) \\
\hline African tigerfishes (Hydrocyninae) \\
\hline airbreathing catfishes (Clariidae) $)^{2}$ \\
\hline candiru catfishes (Trichomycteridae) \\
\hline freshwater electric eels (Electrophoridae) \\
\hline lampreys (Petromyzontidae) \\
\hline piranhas and pirambebas (Serrasalminae) \\
\hline snakeheads (Channidae) \\
\hline tilapias $^{3}$ \\
\hline trahiras or tigerfishes (Erythrinidae) \\
\hline airsac catfishes (Heteropneustidae) \\
\hline green sunfish (Lepomis cyanellus) \\
\hline Australian crayfish (Cherax) ${ }^{4}$ \\
\hline zebra mussels (Dreissena polymorpha) \\
\hline mitten crabs (Eriocheir) $)^{5}$ \\
\hline b. Saltwater \\
\hline sea snakes (Hydrophiidae) ${ }^{7}$ \\
\hline weeverfishes (Trachinidae) \\
\hline stonefishes (Synanceia) \\
\hline $\begin{array}{l}{ }^{1} \text { FAC } 2003 \text {; } \\
{ }^{2} \text { except Clarias batrachus; } \\
{ }^{3} \text { Tilapia, Sarotherodon, and Oreochromis, all species } \\
\text { except Tilapia (Oreochromis) aurea, T. (O.) hornorum, } \\
\text { T. (O.) mossambica, and T. (O.) nilotica; } \\
\text { except for tank aquaculture of Cherax quadricarinatus; } \\
5 \text { or any part thereof; } \\
{ }^{6} \text { Florida Statutes } 2004 a ; \\
{ }^{7} \text { except as provided in Florida Statutes } 370.081(4) \text {. }\end{array}$ \\
\hline
\end{tabular}


Table 2. Fish and other aquatic organisms restricted in Florida $^{1}$

\begin{tabular}{||l||}
\hline \hline bighead carp (Aristichthys nobilis) \\
\hline bony-tongue fishes (Osteoglossidae) ${ }^{2}$ \\
\hline dorados (Salminus) \\
\hline freshwater stingrays (Potamotrygonidae) \\
\hline grass carp (Ctenopharyngodon idella) ${ }^{3}$ \\
\hline Nile perches (Lates) \\
\hline silver carp (Hypophthalmichthys molitrix) \\
\hline snail or black carp (Mylopharyngodon piceus) \\
\hline tilapias ${ }^{4}$ \\
\hline walking catfish (Clarias batrachus) \\
\hline Australian red claw crayfish (Cherax quadricarinatus) ${ }^{5}$ \\
\hline blue catfish (Ictalurus furcatus) ${ }^{6}$ \\
\hline red swamp crayfish (Procambarus clarkii) ${ }^{7}$ \\
\hline white river crayfish (Procambarus zonangulas) \\
\hline${ }^{7}$ FAC $2003 ;$ \\
${ }^{2}$ except silver arowana (Osteoglossum bicirrhosum); \\
${ }^{3}$ restrictions and requirements described in Rule \\
68 A-23.088 F.A.C.; \\
${ }^{4}$ Tilapia (Oreochromis) aurea, $T$. (O.) hornorum, \\
T. (O.) mossambica, and $T$. (O.) nilotica. \\
Tilapia (O.) aurea may be possessed, cultured, and \\
transported without permit in the following areas: North \\
Central Region (Citrus County only) and Northeast, \\
South, and Southwest regions; \\
${ }^{5}$ tank culture systems only; $^{6}$ except north and west of the Suwannee River where \\
blue catfish may be possessed without permit; \\
${ }^{7}$ pond aquaculture is prohibited; may be possessed west \\
of the Apalachicola River or imported for direct sale to \\
food wholesalers and food retailers for re-sale to \\
consumers without permit. \\
\\
\hline \hline
\end{tabular}

It is the landowner's responsibility to prevent the establishment of populations of non-native fish (FAC 2003); however, by policy, landowners are not held responsible for intrusions onto their property or aquaculture facility by species that are established in open waters of the state and are widespread (e.g., walking catfish; Box 1). Any fish (or other aquatic organism) that is determined by the Executive Director of FWC to be detrimental can be confiscated and destroyed as a public nuisance (FAC 2003).
These regulations give FWC broad authority to protect the aquatic resources of Florida through eradication of reproducing or non-reproducing populations of non-native fishes (and other aquatic organisms) and a clear mandate for enforcing state restricted and prohibited species lists.

In addition to rule-making and enforcement responsibilities, FWC has important administrative, management, research, and public education functions concerning non-native fishes in Florida.

Box 1. Asian Swamp Eels and Walking Catfish on Aquaculture Facilities.

Some producers have expressed concern over potential regulatory action against them if their facility is invaded by Asian swamp eels. The Asian swamp eel, although it has received considerable press and agency attention, is not specially listed by Florida or the U.S. federal government and is thus regulated like any other non-native fish in the state. Therefore, state and federal agencies will not take legal or regulatory action against Florida aquaculture producers that have pest Asian swamp eels on their property. By way of comparison, walking catfish is listed as a restricted species in Florida in Rule 68A-23.008(2) F. A.C. and as "injurious wildlife" by the USFWS (50 CFR 16.13). Walking catfish has invaded fish farms in Florida since the 1960s, but its presence as a pest is not grounds for legal or regulatory action.

\section{Florida Department of Agriculture and Consumer Services (DACS)}

The DACS, Division of Aquaculture, has regulatory authority over all aquaculture facilities in Florida. Each aquaculture facility must be inspected and certified by DACS. Aquaculture certificates are issued annually and they list the aquatic species (usually to family or genus level) that the facility may culture. Written authorization is required to possess or culture restricted species. A unique certificate number must be included on all pertinent records associated with the shipment or sale of aquaculture products (e.g., invoices, receipts, and bills of lading). 
Florida Aquaculture Best Management Practices (BMPs) govern the conduct of aquaculture and this program is administered by DACS (DACS 2005). There are general aquaculture BMPs as well as BMPs specific to certain groups (e.g., sturgeon) or production systems. A certified producer must comply with all appropriate BMPs. The BMPs incorporate practices for biosecurity and prevention of escape and are consistent with Florida statutes and FWC rules. In brief, all production facilities must take steps to reduce the possibility of escape by non-native fishes through implementation of redundant management or physical controls, including, for example, maintenance of pond berms at least one foot above the 100-year flood elevation, screening of outlets, chemical sterilization of discharge, stocking native predaceous fish into detention ponds, or fencing of property.

Certified facilities are subject to unannounced BMP compliance visits by DACS staff. During these visits, DACS personnel inspect the facility, including the species cultured and the design, operation, and management of production systems to determine if BMPs have been effectively implemented and maintained. Facilities not in compliance receive on-site guidance followed by written communication including a course of corrective action. Violation and non-compliance may result in suspension or revocation of the facility's aquaculture certificate and an administrative fine.

All parties interested in conducting aquaculture in Florida should read the most current edition of the BMPs and consult with DACS, Division of Aquaculture (See Appendix).

\section{United States Fish and Wildlife Service (USFWS)}

The USFWS has general regulatory and enforcement authority over importation of fish into the US and over their interstate transportation. Fish may be listed as "injurious wildlife" and thereby placed under the Lacey Act, which prohibits their importation and interstate transfer. Currently, walking catfish and snakeheads (Family Channidae) are listed as injurious wildlife under 50 CFR 16.13 (USFWS 2002). These species are already listed in
Florida - walking catfish is restricted and snakeheads are prohibited in the Florida Administrative Code (FAC 2003). Other species of potential interest to Florida aquaculturists (but also currently restricted in Florida) have been proposed for listing as "injurious wildlife" (e.g., black carp) or are currently under scrutiny by the USFWS (e.g., bighead carp and silver carp).

The USFWS inspects shipments of fish imported into the United States. The USFWS has designated certain ports for consolidation and more efficient processing of wildlife imports and exports. In Florida, Miami is a designated port and major port-of-entry for ornamental fish and, to a lesser extent, non-native food fish. Non-designated ports may be used only if inspection services are available. For example, Tampa is a non-designated port, but numerous shipments are processed there. The USFWS requires an Import/Export License for such activities (USFWS 2003) and all shipments must be declared on Form Number 3-177 (USFWS 2001). Information on inspection of shipments and import/export regulations may be obtained from the Miami Port (for Miami), Clermont Supervisory (for Tampa), or Atlanta Regional (for Miami or Tampa) offices of the USFWS (see Appendix) and the USFWS wildlife import/export Web site (USFWS 2004). DACS, Division of Aquaculture also can assist producers with information on importing and exporting.

\section{Summary}

Non-native species comprise the bulk of aquaculture in Florida. These species are important economically, and there are regulations concerning their possession, sale, and transportation. The FWC has the primary role in regulating and managing non-native fish in Florida. DACS regulates and certifies all aquaculture facilities in Florida, and it publishes aquaculture BMPs that include provisions for biosecurity and prevention of escape by non-native species. Lastly, the USFWS regulates importation and interstate transfer of non-native fishes. It is important for producers to stay informed about current regulations relating to non-native species. 


\section{References}

DACS. 2005. Aquaculture Best Management

Practices Manual. Florida Department of Agriculture and Consumer Services, Division of Aquaculture, Tallahassee, FL.

http://www.floridaaquaculture.com/Pub.htm

FAC. 2003. Florida Administrative Code

68A-23.008. http://fac.dos.state.fl.us

FASS. 2004. Aquaculture. Florida Agricultural Statistics Service, Orlando, FL.

http://www.nass.usda.gov/fl

Florida Constitution. 2005. Article IV, Section 9. http://www.leg.state.fl.us/Statutes/ index.cfm?Mode $=$ Constitution $\&$ Submenu $=3 \& T a b=$ st atutes\#A04S09

Florida Statutes. 2004a. Florida Statute 370.081. http://flsenate.gov/statutes

Florida Statutes. 2004b. Florida Statute 372.26. http://flsenate.gov/statutes

FWC. 2005. Exotic freshwater fishes. http://www.myfwc.com/fishing/Fishes/nonnative.html

Hill, J. E. 2002. Exotic fishes in Florida. Lakelines, North American Lake Management Society 22(1):39-43. http://www.nalms.org/lakeline/pdf/l122-1_hill.pdf

USFWS. 2001. Form Number 3-177, Declaration for Importation or Exportation of Fish or Wildlife.
http://www.fws.gov/le/ImpExp/faqs.htm (also available at http://www.fws.gov/forms/)

USFWS. 2002. Current list of injurious wildlife species found at 50 CFR 16.11-16.15 (10/4/2002). U.S. Fish and Wildlife Service, Division of Environmental Quality, Arlington, VA. http://contaminants.fws.gov/OtherDocuments/ InjuriousWildlifeList.htm

USFWS. 2003. USFWS Law Enforcement permit issuing offices. http://www.fws.gov/le/ImpExp/ Regional_Permit_Offices.htm

USFWS. 2004. Importing and exporting your commercial wildlife shipment. U.S. Fish and Wildlife Service, Office of Law Enforcement, Arlington, VA. http://www.fws.gov/le/ImpExp/ CommWildlifeImportExport.htm

USGS. 2005. Nonindigenous aquatic species database. U.S. Geological Survey, Gainesville, FL. http://nas.er.usgs.gov

\section{Appendix}

Florida Department of Agriculture

and Consumer Services

Division of Aquaculture

1203 Governors Square Boulevard

Fifth Floor

Tallahassee, FL 32301

$850-488-4033$ or $488-5471$

aquaculture_web@doacs.state.fl.us

http://www.floridaaquaculture.com 
404-679-7057

Florida Fish and Wildlife Conservation Commission

Division of Freshwater Fisheries Headquarters

620 South Meridian Street

Tallahassee, FL 32399

$850-488-0331$

http://www.myfwc.com

Florida Fish and Wildlife Conservation Commission

Division of Law Enforcement

620 South Meridian Street

Tallahassee, FL 32399

$850-488-0251$

http://www.myfwc.com

University of Florida

Institute of Food and Agricultural Sciences

Department of Fisheries and Aquatic Sciences

Tropical Aquaculture Laboratory

$140824^{\text {th }}$ Street SE

Ruskin, FL 33570

$813-671-5230$

http://tal.ifas.ufl.edu

U.S. Fish and Wildlife Service

Atlanta Regional Office-Law Enforcement

1875 Century Boulevard, Suite 380

Atlanta, GA 30345
http://southeast.fws.gov/law/Regional\%20Office.htm

U.S. Fish and Wildlife Service

Clermont, FL Supervisory Office—Law Enforcement

P.O. Box 676

Minneola, FL 34755

$352-394-4060$

http://southeast.fws.gov/law/RAC/Clermont.htm

U.S. Fish and Wildlife Service

Miami Port

$10426 \mathrm{NW} 31^{\text {st }}$ Terrace

Miami, FL 33172

$305-526-2610$

http://southeast.fws.gov/law/PORT/miamiport.htm 